\section{Organized Access to the Ibero-American Quality Journals: The PPL Experience}

\author{
Ana María Cetto \& José Octavio Alonso-Gamboa \\ Universidad Nacional Autónoma de México \\ Saray Córdoba González \\ Universidad de Costa Rica \\ Elea Giménez-Toledo \\ Consejo Superior de Investigaciones Científicas, Spain \\ Guillermo Chávez Sánchez \\ Universidad Nacional Autónoma de México
}

\begin{abstract}
Latindex has created a portal of portals (PPL) aimed at providing free and open organized access to the literature published in Ibero-American scholarly journals. A report on the initial experience with the PPL is presented, with a critical overview of the main features and shortcomings found in the harvesting process. Our findings raise the need for additional information sources in Ibero-America and for the portals to adopt and adhere to technical and editorial standards. Further, the coverage of journals by different systems providing quality indicators is analyzed, based on case studies of journals produced in two countries with different degrees of development. This analysis highlights the relevant role that PPL can play in support of Ibero-American journals and as a tool in evaluation processes.
\end{abstract}

\section{Keywords}

Scientific journals; Open access; Portals; Ibero-America; Editorial quality

\section{CCSP Press}

Scholarly and Research Communication

Volume 4, Issue 1, Article ID o10135, 19 pages

Journal URL: www.src-online.ca

Received January 13, 2012, Accepted March 2, 2012, Published August 30, 2012

Ana María Cetto, José Octavio Alonso-Gamboa, Saray Córdoba González, Elea Giménez-Toledo, Guillermo Chávez Sánchez. (2012). Organized access to the Ibero-American quality journals: The PPL experience. Scholarly and Research Communication, 4(1): 010135, 19 pp.

(C) 2012 Ana María Cetto, José Octavio Alonso-Gamboa, Saray Córdoba González, Elea Giménez-Toledo, Guillermo Chávez Sánchez. This Open Access article is distributed under the terms of the Creative Commons Attribution Non-Commercial License (http://creativecommons.org/licenses/by-nc-nd/2.5/ ca), which permits unrestricted non-commercial use, distribution, and reproduction in any medium, provided the original work is properly cited.
Scholarly and Research

Communication

VOLUme 4 / ISSUE 1 / 2013

Ana María Cetto is Research Professor at the Universidad Nacional Autónoma de México, Apartado postal 20-364, o10oo México, D.F. Email: ana@fisica.unam.mx .

José Octavio Alonso-Gamboa is Coordinator General of Latindex at the Universidad Nacional Autónoma de México, Av. Universidad 30oo, o4510 México, D.F. Email: oalonso@unam.mx.

Saray Córdoba González is Latindex Representative at the Universidad de Costa Rica, Ciudad Universitaria Rodrigo Facio, 206o San Pedro, Costa Rica. Email: saraycg@gmail. com .

Elea Giménez-Toledo is Research Fellow at the Consejo Superior de Investigaciones Científicas, C/ Albasanz, 26-28, 28037 Madrid, Spain. Email: elea. gimenez@cchs.csic.es .

Guillermo Chávez Sánchez is Head of Digital Publishing at the Universidad Nacional Autónoma de México, Av. Universidad 3000 , 04510 México, D.F. Email: gchavezs@unam.mx . 
Scholarly and Research

\section{Communication}

VOLUME 4 / ISSUE 1 / 2013

\section{Resumé}

Latindex a créé un portail de portails (PPL) destiné à fournir un accès organisé libre et ouvert à la littérature publiée dans les journaux scientifiques ibéro-américains. On présente un rapport sur l'expérience initiale, avec une revue critique des caractéristiques principales et des problèmes rencontrés durant la récolte. On montre la nécessité de sources d'information additionnelles dans la région et que les portails adoptent et suivent des normes techniques et éditoriales. De plus, sur la base détudes de cas dans deux pays de degrés de développement différents, on analyse le traitement de journaux par des systèmes fournissant des indices de qualité. Cette analyse met en évidence le rôle que le PPL peut jouer en plus comme appui des journaux ibéroaméricains et comme outil de processus d'évaluation.

\section{Mots clés}

Journaux scientifiques; Libre accès; Portails; Ibéro-amérique; Qualité editoriale

\section{Introduction}

Nearly half a century ago, a number of scientists, editors, and librarians, among others, started to show a clear interest in gaining better knowledge of the scholarly journals published in Spanish- and Portuguese-speaking countries. Two notable precursors of this movement in Latin America were the meetings in Mexico City in 1962 and in Río Piedras, Puerto Rico, in 1964. The former resulted in a first attempt at quantifying the journals published in the region, while the latter issued a call to conduct evaluation exercises aimed at identifying the best publications in the various areas of knowledge.

Since then, much has happened with regard to Ibero-American journals. A noteworthy step taken in the early seventies was the creation of the first bibliographical databases for journals, namely ISOC, ICYT, and IME in Spain, CLASE and Periódica in Mexico, and LILACS in Brazil, all of which continue to be active (Alonso-Gamboa \& Russell, 2012).

All these efforts, however, could hardly lead to a complete and integrated picture of the scholarly periodical publications in the region. ${ }^{1}$ The need to improve both our knowledge of the journals and their quality led to the creation of Latindex in 1997. Its two main products responded to the concerns expressed more than three decades earlier through both the Directory, which contains information on the entire range of titles, and the Catalogue, which identifies those journals that comply with editorial quality standards. Latindex was born just as the region was starting to use the Internet and electronic publishing more intensely as tools to strengthen scholarly journal publishing.

On the other hand, the dawn of this century has witnessed the emergence of a strong movement toward open access to scientific literature. Although this movement arose to a large extent as a consequence of an essentially economic problem created by the endless and often inordinate rise of subscription prices (McCabe, 2001, 2002; Borrego Huerta, 2006), its flourishing in Ibero-America is linked to the fact that publicly funded universities and research institutions produce by far the largest part of scientific papers and journals. This facilitates offering this scientific production 
free of subscription costs or other restrictions to the broad public (Dávila, Núñez, Sandia, \& Torréns, 2006). As a result, a number of portals have been created with the purpose of increasing the access and visibility of scholarly journals and incorporating technology for their editorial and manuscript management. In most cases, the journal titles included in these portals have been subject to some kind of assessment, so as to ensure the quality of the material made available (Cetto, Alonso-Gamboa, \& Córdoba González, 2010).

As an information system of wide regional coverage, Latindex has been registering both the evolution of online journal publishing and the emergence of journal portals, in particular of those that adhere to the open access movement. For this reason, and in response to a number of recommendations, ${ }^{2}$ it was decided to create the Portal of Portals (Portal de Portales Latindex, or PPL see www.latindex.ppl.unam.mx), so as to offer organized access to a growing collection of articles that can be harvested through a selection of existing journal portals by means of the Open Archives InitiativeProtocol for Metadata Harvesting (OAI-PMH). As an aggregator of specialized information, the PPL thus offers a single entry point to the full text of all those IberoAmerican journals that are available through any of the portals selected.

Based on the material harvested by the PPL, this paper contains a critical summary of the initial harvesting experience, followed by a comparative analysis of two sets of journals from countries with different degrees of development. Further, two issues are highlighted and discussed: the role played by Latindex in supporting journal evaluation processes and research evaluation, and the impact of the system on improving the quality of journals and their presence in both regional and international information systems. The paper ends with a discussion on how the PPL is expected to enhance the use and visibility of the Ibero-American scholarly literature.

\section{Basic features of portals harvested by the PPL}

The actual PPL work started with a definition of the conceptual and technological framework that would guide the development of the system. Only portals were included that would:

- follow a construction methodology that ensures a normalized contents description;

- $\quad$ apply selection procedures for the inclusion of journals and publish their selection criteria; and

- use a technology platform that allows the harvesting of documents through protocols of interoperability.

A first directory of portals was prepared, resulting in a total of 29 with open access; only one portal had to be dismissed for operating on a subscription basis. ${ }^{3}$
VOLUME 4 / ISSUE 1 / 2013 
Scholarly and Research

\section{Communication}

VOLUME 4 / ISSUE 1 / 2013
In the first construction phase, a meta-harvester was developed, and associated hardware and software tools were adapted to deal with the diversity of existing portals. The OAI-PMH, a widely used protocol for the exchange of metadata based on a clientserver model, was adapted to the needs of the project. The PPL, as the service provider, requests the provision of metadata in Dublin Core format from the portals (as data providers) (UNAM, 2010). A first analysis left out a total of eight portals that did not adjust to this protocol, while another six portals could not be initially included due to difficulties with the automated data harvesting. A first evaluation of the technical difficulties encountered suggests promoting standardized use of this harvesting protocol among the various journal portals. One positive outcome of this experience has been the feedback provided by the PPL technicians to the portal editors.

The 18 portals harvested up to September 2011 are listed in Table 1. A global analysis of these portals gives the following picture:

- Most portals (15) are multidisciplinary; only PePSIC, SciELO-Cuba, and SciELOSpain are restricted to certain disciplines.

- All 18 portals provide information about their journal selection process, based on international editorial selection criteria.

- Eight portals are operated by national science and technology (S\&T) centres, and another eight by universities. The remaining two are the product of the cooperative work of other organizations.

- The creation of SciELO-Brazil and SciELO-Chile dates back to 1997; all other portals from the list have been created during the past decade.

- The number of journals covered by the individual portals ranges from 11 to 758 , and the number of full-text articles per portal ranges from 283 to 200,000 . The total number of documents exceeds one million; however, there is considerable overlap of journals and duplication of articles.

Table 1: Portals of Ibero-American journals harvested by the PPL (data taken from the portals in September 2011)

\begin{tabular}{|l|l|l|l|}
\hline Portal & $*$ URL & $\begin{array}{l}\text { Publisher } \\
\text { (country) }\end{array}$ & Main features \\
\hline 1. DIALNET & $\begin{array}{l}\text { http://dialnet. } \\
\text { unirioja.es }\end{array}$ & $\begin{array}{l}\text { Universidad de la } \\
\text { Rioja (Spain) }\end{array}$ & $\begin{array}{l}\text { Titles: 1,816 (on own server } \\
\text { or through links) } \\
\text { Articles: } 383,467 \\
\text { Themes: Multidisciplinary } \\
\text { First year: 2001 }\end{array}$ \\
\hline 2. e-revist@s & $\begin{array}{l}\text { http://www. } \\
\text { erevistas.csic.es }\end{array}$ & $\begin{array}{l}\text { Consejo Superior } \\
\text { de Investigaciones } \\
\text { Científicas (Spain) }\end{array}$ & $\begin{array}{l}\text { Titles: } 509 \\
\text { Articles: 127,825 } \\
\text { Themes: Multidisciplinary } \\
\text { First year: 2004 }\end{array}$ \\
\hline
\end{tabular}
experience. Scholarly and Research Communication, 4(1): 010135, 19 pp. 


\begin{tabular}{|c|c|c|c|}
\hline Portal & ${ }^{*} \mathrm{URL}$ & $\begin{array}{l}\text { Publisher } \\
\text { (country) }\end{array}$ & Main features \\
\hline $\begin{array}{l}\text { 3. Latin } \\
\text { American } \\
\text { Journals } \\
\text { Online } \\
\text { (LAMJOL) }\end{array}$ & $\begin{array}{l}\text { http://www. } \\
\text { lamjol.info }\end{array}$ & $\begin{array}{l}\text { International } \\
\text { Network for } \\
\text { the Availability } \\
\text { of Scientific } \\
\text { Publications } \\
\text { (INASP), } \\
\text { Programme for } \\
\text { the Enhancement } \\
\text { of Research } \\
\text { Information } \\
\text { (PERii) }\end{array}$ & $\begin{array}{l}\text { Titles: } 11 \\
\text { Articles: } 283 \\
\text { Themes: Multidisciplinary } \\
\text { First year: } 2011\end{array}$ \\
\hline $\begin{array}{l}\text { 4. PePSIC: } \\
\text { Revistas } \\
\text { Electrónicas } \\
\text { en Psicología }\end{array}$ & $\begin{array}{l}\text { http://PePSIC. } \\
\text { bvs-psi.org.br/ } \\
\text { scielo.php }\end{array}$ & $\begin{array}{l}\text { Biblioteca Virtual } \\
\text { en Salud - } \\
\text { Psicología (BVS- } \\
\text { Psi), Asociación } \\
\text { Brasileña de } \\
\text { Editores Científicos } \\
\text { de Psicología - } \\
\text { ABECiP (Brazil) }\end{array}$ & $\begin{array}{l}\text { Titles: } 84 \\
\text { Issues: } 840 \\
\text { Themes: Psychology } \\
\text { First year: Undefined }\end{array}$ \\
\hline $\begin{array}{l}\text { 5. Portal de } \\
\text { revistas de la } \\
\text { Universidad } \\
\text { de Chile }\end{array}$ & $\begin{array}{l}\text { http://www. } \\
\text { revistas.uchile.cl }\end{array}$ & $\begin{array}{l}\text { Universidad de } \\
\text { Chile }\end{array}$ & $\begin{array}{l}\text { Titles: } 106 \\
\text { Articles: } 13,583 \\
\text { Themes: Multidisciplinary } \\
\text { First year: } 2011\end{array}$ \\
\hline $\begin{array}{l}\text { 6. Portal de } \\
\text { revistas da } \\
\text { Universidade } \\
\text { Federal do } \\
\text { Paraná }\end{array}$ & $\begin{array}{l}\text { http://ojs.c3sl. } \\
\text { ufpr.br/ojs2 }\end{array}$ & $\begin{array}{l}\text { Universidade } \\
\text { Federal do Paraná } \\
\text { (Brazil) }\end{array}$ & $\begin{array}{l}\text { Titles: } 49 \\
\text { Articles: } 13,861 \\
\text { Themes: Multidisciplinary } \\
\text { First year: Undefined }\end{array}$ \\
\hline $\begin{array}{l}\text { 7. RACO: } \\
\text { Revistes } \\
\text { Catalanes } \\
\text { amb Accés } \\
\text { Obert }\end{array}$ & $\begin{array}{l}\text { http://www.raco. } \\
\text { cat/index.php/ } \\
\text { index }\end{array}$ & $\begin{array}{l}\text { Consorci de } \\
\text { Biblioteques } \\
\text { Universitàires de } \\
\text { Catalunya }\end{array}$ & $\begin{array}{l}\text { Titles: } 333 \\
\text { Issues: } 7,001 \\
\text { Articles: } 116,054 \\
\text { Themes: Multidisciplinary } \\
\text { First year: } 2006\end{array}$ \\
\hline 8. Redalyc & $\begin{array}{l}\text { http://redalyc. } \\
\text { uaemex.mx }\end{array}$ & $\begin{array}{l}\text { Universidad } \\
\text { Autónoma del } \\
\text { Estado de México - } \\
\text { UAEM (Mexico) }\end{array}$ & $\begin{array}{l}\text { Titles: } 758 \\
\text { Articles: } 190,645 \\
\text { Themes: Multidisciplinary } \\
\text { First year: } 2003\end{array}$ \\
\hline $\begin{array}{l}\text { 9. Revistas } \\
\text { científicas y } \\
\text { arbitradas de } \\
\text { la UNAM }\end{array}$ & $\begin{array}{l}\text { http://www. } \\
\text { journals.unam. } \\
\text { mx }\end{array}$ & $\begin{array}{l}\text { Universidad } \\
\text { Nacional } \\
\text { Autónoma de } \\
\text { México - UNAM } \\
\text { (Mexico) }\end{array}$ & $\begin{array}{l}\text { Titles: } 56 \\
\text { Issues: } 1,301 \\
\text { Articles: } 14,986 \\
\text { Themes: Multidisciplinary } \\
\text { First year: } 2010\end{array}$ \\
\hline
\end{tabular}

Scholarly and Research

Communication

VOLUME 4 / ISSUE 1 / 2013 
Scholarly and Research

\section{Communication}

VOLUME 4 / ISSUE 1 / 2013

\begin{tabular}{|c|c|c|c|}
\hline Portal & * URL & $\begin{array}{l}\text { Publisher } \\
\text { (country) }\end{array}$ & Main features \\
\hline 10. Saber ULA & $\begin{array}{l}\text { http://www.saber. } \\
\text { ula.ve }\end{array}$ & $\begin{array}{l}\text { Universidad de Los } \\
\text { Andes (Venezuela) }\end{array}$ & $\begin{array}{l}\text { Titles: } 78 \\
\text { Articles: } 13,145 \\
\text { Themes: Multidisciplinary } \\
\text { First year: Undefined }\end{array}$ \\
\hline $\begin{array}{l}\text { 11. SciELO - } \\
\text { Argentina }\end{array}$ & $\begin{array}{l}\text { http://www. } \\
\text { scielo.org.ar/ } \\
\text { scielo.php }\end{array}$ & $\begin{array}{l}\text { Consejo Nacional } \\
\text { de Investigaciones } \\
\text { Científicas } \\
\text { y Técnicas - } \\
\text { CONICET } \\
\text { (Argentina) }\end{array}$ & $\begin{array}{l}\text { Titles: } 74 \\
\text { Issues: } 898 \\
\text { Articles: } 11,143 \\
\text { Themes: Multidisciplinary } \\
\text { First year: } 2004\end{array}$ \\
\hline $\begin{array}{l}\text { 12. SciELO - } \\
\text { Brasil }\end{array}$ & $\begin{array}{l}\text { http://www. } \\
\text { scielo.br/scielo. } \\
\text { php?script=sci_ } \\
\text { home\&lng= } \\
\text { es\&nrm=iso }\end{array}$ & $\begin{array}{l}\text { Fundação de } \\
\text { Amparo à Pesquisa } \\
\text { do Estado de São } \\
\text { Paulo - FAPESP } \\
\text { (Brazil); Centro } \\
\text { Latino americano } \\
\text { y del Caribe de } \\
\text { Información en } \\
\text { Ciencias de la Salud } \\
\text { - BIREME (Brazil); } \\
\text { and Conselho } \\
\text { Nacional de } \\
\text { Desenvolvimento } \\
\text { Científico e } \\
\text { Tecnológico - } \\
\text { CNPq (Brazil) }\end{array}$ & $\begin{array}{l}\text { Titles: } 255 \text { ( } 228 \text { active and } \\
27 \text { ceased) } \\
\text { Issues: } 9,449 \\
\text { Articles: } 187,346 \\
\text { Themes: Multidisciplinary } \\
\text { First year: } 1997\end{array}$ \\
\hline $\begin{array}{l}\text { 13. SciELO - } \\
\text { Chile }\end{array}$ & $\begin{array}{l}\text { http://www. } \\
\text { scielo.cl/?lang=es }\end{array}$ & $\begin{array}{l}\text { Comisión Nacional } \\
\text { de Investigaciones } \\
\text { Científicas y } \\
\text { Tecnológicas - } \\
\text { CONICYT } \\
\text { (Chile) }\end{array}$ & $\begin{array}{l}\text { Titles: } 92 \\
\text { Issues: } 2,216 \\
\text { Articles: } 23,104 \\
\text { Themes: Multidisciplinary } \\
\text { First year: } 1997\end{array}$ \\
\hline $\begin{array}{l}\text { 14. SciELO - } \\
\text { Colombia }\end{array}$ & $\begin{array}{l}\text { http://www. } \\
\text { scielo.org.co/ } \\
\text { scielo.php/ } \\
\text { script_sci_home/ } \\
\text { lng_es/nrm_iso }\end{array}$ & $\begin{array}{l}\text { Colciencias, } \\
\text { Organización } \\
\text { Panamericana de } \\
\text { la Salud - PAHO } \\
\text { and Universidad } \\
\text { Nacional de } \\
\text { Colombia } \\
\text { (Colombia) }\end{array}$ & $\begin{array}{l}\text { Titles: } 106 \\
\text { Issues: } 1,156 \\
\text { Articles: } 12,341 \\
\text { Themes: Multidisciplinary } \\
\text { First year: } 2004\end{array}$ \\
\hline $\begin{array}{l}\text { 15. SciELO - } \\
\text { Cuba }\end{array}$ & $\begin{array}{l}\text { http://scielo.sld. } \\
\mathrm{cu} / \text { scielo.php }\end{array}$ & $\begin{array}{l}\text { Red Telemática de } \\
\text { Salud en Cuba - } \\
\text { INFOMED (Cuba) }\end{array}$ & $\begin{array}{l}\text { Titles: } 36 \\
\text { Issues: } 1,125 \\
\text { Articles: } 13,059 \\
\text { Themes: Agricultural and } \\
\text { Health Sciences } \\
\text { First year: } 2001\end{array}$ \\
\hline
\end{tabular}




\begin{tabular}{|c|c|c|c|}
\hline Portal & * URL & $\begin{array}{l}\text { Publisher } \\
\text { (country) }\end{array}$ & Main features \\
\hline $\begin{array}{l}\text { 16. SciELO - } \\
\text { España }\end{array}$ & $\begin{array}{l}\text { http://scielo. } \\
\text { isciii.es/scielo. } \\
\text { php }\end{array}$ & $\begin{array}{l}\text { Biblioteca Nacional } \\
\text { de Ciencias de la } \\
\text { Salud (Spain) }\end{array}$ & $\begin{array}{l}\text { Titles: } 46 \\
\text { Issues: } 1,321 \\
\text { Articles: } 16,747 \\
\text { Themes: Health Sciences } \\
\text { First year: } 2001\end{array}$ \\
\hline $\begin{array}{l}\text { 17. SciELO - } \\
\text { México }\end{array}$ & $\begin{array}{l}\text { http://www. } \\
\text { scielo.org.mx/ } \\
\text { scielo.php }\end{array}$ & $\begin{array}{l}\text { Dirección General } \\
\text { de Bibliotecas } \\
\text { (DGB) - UNAM } \\
\text { (Mexico) }\end{array}$ & $\begin{array}{l}\text { Titles: } 84 \text { ( } 76 \text { active and } 8 \\
\text { ceased) } \\
\text { Issues: } 652 \\
\text { Articles: } 7,429 \\
\text { Themes: Multidisciplinary } \\
\text { First year: } 2003\end{array}$ \\
\hline $\begin{array}{l}\text { 18. SciELO - } \\
\text { Perú }\end{array}$ & $\begin{array}{l}\text { http://www. } \\
\text { scielo.org.pe/ } \\
\text { scielo.php }\end{array}$ & $\begin{array}{l}\text { Consejo Nacional } \\
\text { de Ciencia, } \\
\text { Tecnología e } \\
\text { Innovación } \\
\text { Tecnológica - } \\
\text { CONCYTEC, } \\
\text { Universidad } \\
\text { Nacional Mayor } \\
\text { de San Marcos and } \\
\text { PAHO-Peru (Peru) }\end{array}$ & $\begin{array}{l}\text { Titles: } 13 \\
\text { Issues: } 324 \\
\text { Articles: } 3,858 \\
\text { Themes: Multidisciplinary } \\
\text { First year: } 2004\end{array}$ \\
\hline
\end{tabular}

Scholarly and Research

Communication

VOLUME 4 / ISSUE $1 / 2013$

The portals use either DSpace or OJS, which have an information architecture that facilitates more transparent interoperability, as compared to applications that do not comply with the basic technical criteria for open access. One problem encountered during the first harvesting, however, was a lack of compatibility in the implementation and configuration of the protocol OAI-PMH for the interoperability of systems, or even non-implementation of the protocol; this represented an obstacle for the harvesting of metadata or inclusion of portals in nearly $30 \%$ of the cases.

Another deficiency is the poor use of Dublin Core labels for the description of document contents, with only a handful of the 15 required labels being used in some cases. Further, there is some discrepancy in the treatment of the information and in the way it is provided to users. For example, while some portals display full information in their registers, others use codes or abbreviations (e.g., "español" vs. "es"). More serious in this regard are the problems created by the various ways in which the same labels are used. For instance, some portals use the label "editor" ("publisher," in English) to identify the publishing institution, whilst others apply it to the journal title. The problems encountered are being solved by communicating them directly to the portal editors and by using the tools provided by the same OAI-PMH. 
Scholarly and Research

VOLUME 4 / ISSUE 1 / 2013
Impact of Latindex and the PPL on journal publishing and science evaluation policy: The cases of Costa Rica and Spain

Visibility OF JOURNALS IN A LESS DEVELOPED COUNTRY: THE CASE OF Costa Rica

With 4.6 million inhabitants living in an area of $51,000 \mathrm{sq} \mathrm{km},{ }^{4}$ Costa Rica is the third least populated country in Central America, followed only by Panama and Belize.

Yet, the country has one of the highest educational levels and the highest scientific production of the region. It produces the only journal from Central America (Revista de Biología Tropical) indexed by Web of Science (WoS) and Scopus. The University of Costa Rica (UCR), which alone is responsible for $56 \%$ of this scientific production, is today in the $16^{\text {th }}$ place among the Latin American universities listed in the Ranking Web of World Universities (see http://www.webometrics.info/top1oo_continent_ es.asp?cont=latin_america). Being the national Latindex member, the UCR compiles the information on Costa Rican journal titles, trains and gives advice to editors, and assesses the journals for entry into the Catalogue on a yearly basis. In view of the existing gap in this area on a national level, the UCR has assumed the responsibility of evaluating all scholarly journals on the basis of the Latindex criteria. This decision, along with the annual training workshops for editors, has resulted in an overall increase in journal quality, as will be shown below.

We have compared the presence of Costa Rican journals in indexing and abstracting services with their level of qualification in the Latindex Catalogue, on the basis of the percentage of quality parameters met (from a total of 33 parameters for print-on-paper titles and 36 for electronic versions). ${ }^{5}$ There are 270 titles registered in the Latindex Directory, and only 65 of them meet the minimum number of parameters required to be included in the Catalogue; however, only 29 (10.7\%) of these 65 journals are included in at least one of the indexing and abstracting services. The results of this comparison are summarized in Figure 1.

Notice the positive correlation $(r=0.24)$ between the level of qualification of individual journals in the Catalogue and the number of services in which these journals are present. There is evidence to assert that the correlation is significant and statistically different from o $(p=0.05)$. For the group of journals that are present in at least one service, the average level of qualification in Latindex is 90.86, while for the complete set of journals (including those that do not appear in any service) this average is 87.39 . Further, given a specific journal, for every additional service that includes it, we observe on average an increase of 0.275 in its Latindex qualification. Note that no causal relationship is implied between these parameters (number of portals and Latindex qualification).

When compared with 2006 (see Córdoba, 2006), Costa Rican journals have notably increased their presence in indexing and abstracting services, mainly due to the pressure from public universities on their staff to publish in indexed journals. The effects of including them in the PPL will probably be seen in the short term, since this increase in access and visibility is expected to benefit the quality, the number of citations, and the prestige of the journals. 
Figure 1: Diagram showing the correlation between frequency of presence of 29 journals in indexing and abstracting services (horizontal axis) and their level of qualification in the Latindex Catalogue (vertical axis). Source: Latindex (2011).
Scholarly and Research

Communication

VOLUME 4 / ISSUE 1 / 2013

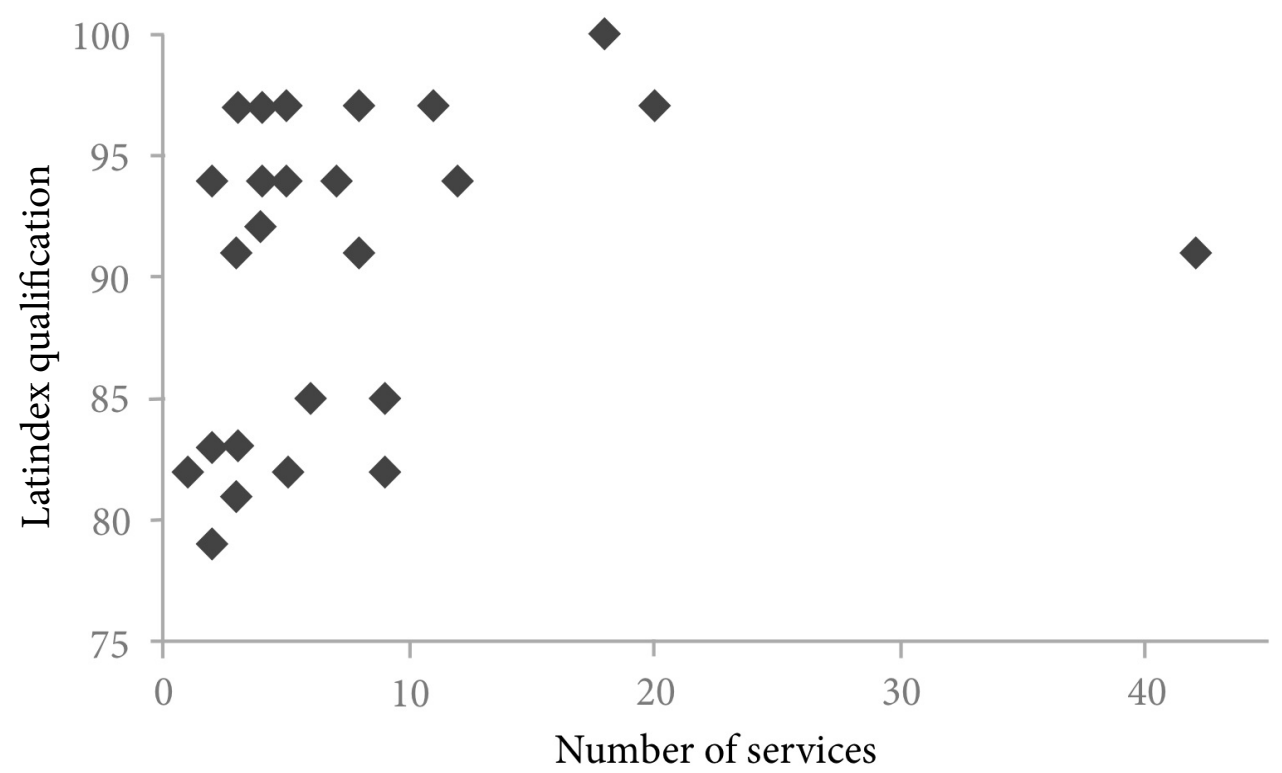

Up to June 28, 2011, a total of 5,445 articles were harvested from Costa Rican journals by the PPL, meaning that the PPL is effectively increasing the visibility of the Costa Rican scholarly production. On the other hand, from the above data it is clear that in their selection process both the individual portals and other services tend to choose those Latindex journals that perform better in the Catalogue, thus leaving out an important fraction of titles. The fact that only $10.7 \%$ of the qualified journals are included in portals indicates that stronger efforts are required to augment the presence of titles in relevant information systems and journal portals. This has been a priority task for Latindex-Costa Rica, as well as a matter of concern among the journal editors who attend the annual training workshops offered by the UCR. In what follows, we report some results of the efforts made so far.

\section{The Presence of journals in ScielO-Costa Rica}

The site http://www.scielo.sa.cr was created by the Biblioteca Nacional de Salud y Seguridad Social (BINASSS) in the year 2000, with nine journal titles published by the Caja Costarricense de Seguro Social (CCSS) and one by the UCR itself. Since 2005, efforts have been made to increase the number of titles, but only recently have the fruits of this effort become visible. After the establishment of an advisory committee in 2009, a review was made of the ten original journals on the basis of the Latindex criteria, and as a result, only five out of ten titles were selected. Since then, another four have qualified for the site.

Once these new journals are uploaded, SciELO-Costa Rica will cover a total of ten titles. Another fifteen titles are under review for possible inclusion in the short term, all of them having been already positively assessed by Latindex. This proposal is supported financially and technically by initiative of the Consejo Nacional de Rectores 
Scholarly and Research Communication

VOLUME 4 / ISSUE 1 / 2013
(CONARE), representing the four major public universities, which are also the main producers of good quality journals in Costa Rica.

Coverage by Redalyc, e-Revistas, Dialnet, and PePSiC

Other systems that cover Costa Rican journals are Redalyc (16 titles), e-Revistas (four titles), Dialnet (21 titles) and PePSIC (one title). Journal editors initiate the process for inclusion of their publication in a portal, but they are supported in this task by the UCR. In addition, a direct channel has been established with Redalyc to promote the inclusion in their portal of further titles, both from Costa Rica as well as from other Central American countries.

Table 2: Costa Rican journals included in the Latindex Catalogue and PPL portals.

Source: Latindex (2011).

\begin{tabular}{|c|c|c|c|}
\hline Journal title & $\begin{array}{l}\text { Latindex } \\
\text { qualification }\end{array}$ & $\begin{array}{l}\text { Presence } \\
\text { in indexing } \\
\text { and } \\
\text { abstracting } \\
\text { services }\end{array}$ & Presence in PPL portals \\
\hline Agronomía Mesoamericana & $100 \%$ & 18 & $\begin{array}{l}\text { SciELO } \\
\text { Redalyc } \\
\text { e-Revistas }\end{array}$ \\
\hline Revista de Biología Tropical & $100 \%$ & 42 & $\begin{array}{l}\text { SciELO } \\
\text { Redalyc } \\
\text { Dialnet }\end{array}$ \\
\hline Actualidades Inv. Educación & $100 \%$ & 6 & $\begin{array}{l}\text { Redalyc } \\
\text { e-Revistas } \\
\text { Dialnet }\end{array}$ \\
\hline Agronomía Costarricense & $97 \%$ & 20 & $\begin{array}{l}\text { SciELO * } \\
\text { Redalyc } \\
\text { e-Revistas } \\
\text { Dialnet }\end{array}$ \\
\hline Acta Médica Costarricense & $97 \%$ & 7 & $\begin{array}{l}\text { SciELO } \\
\text { Redalyc } \\
\text { Dialnet }\end{array}$ \\
\hline $\begin{array}{l}\text { Rev. Geológica de Am. } \\
\text { Central }\end{array}$ & $97 \%$ & 6 & SciELO * \\
\hline Educación & $97 \%$ & 6 & $\begin{array}{l}\text { Redalyc } \\
\text { Dialnet }\end{array}$ \\
\hline Medicina Legal de CR & $97 \%$ & 4 & SciELO \\
\hline $\begin{array}{l}\text { Población y Salud en } \\
\text { Mesoamérica }\end{array}$ & $97 \%$ & 5 & $\begin{array}{l}\text { Redalyc } \\
\text { e-Revistas } \\
\text { Dialnet }\end{array}$ \\
\hline
\end{tabular}

Ana María Cetto, José Octavio Alonso-Gamboa, Saray Córdoba González, Elea Giménez-Toledo, Guillermo Chávez Sánchez. (2012). Organized access to the Ibero-American quality journals: The PPL experience. Scholarly and Research Communication, 4(1): 010135, 19 pp. 


\begin{tabular}{|c|c|c|c|}
\hline Diálogos & $94 \%$ & 3 & $\begin{array}{l}\text { SciELO * } \\
\text { Redalyc } \\
\text { Dialnet }\end{array}$ \\
\hline Ingeniería & $94 \%$ & 4 & None \\
\hline $\begin{array}{l}\text { Revista Estudios Históricos } \\
\text { Masonería LA y Caribeña }\end{array}$ & $94 \%$ & 1 & Dialnet \\
\hline Odontos & $91 \%$ & $\mathrm{o}$ & None \\
\hline Biocenosis & $91 \%$ & 3 & None \\
\hline Revista de Matemática & $91 \%$ & $\mathrm{o}$ & SciELO * \\
\hline Educare & $89 \%$ & 2 & $\begin{array}{l}\text { Redalyc } \\
\text { Dialnet }\end{array}$ \\
\hline MH Salud & $89 \%$ & 2 & $\begin{array}{l}\text { Redalyc } \\
\text { Dialnet }\end{array}$ \\
\hline Revista Derecho Electoral & $89 \%$ & 1 & None \\
\hline Posgrado y Sociedad & $89 \%$ & 1 & Dialnet \\
\hline Reflexiones & $88 \%$ & 5 & $\begin{array}{l}\text { Redalyc } \\
\text { Dialnet }\end{array}$ \\
\hline Rev. Ciencias Económicas & $88 \%$ & 4 & Dialnet \\
\hline Rev. Ciencias Sociales & $88 \%$ & 10 & $\begin{array}{l}\text { Redalyc } \\
\text { Dialnet }\end{array}$ \\
\hline $\begin{array}{l}\text { Rev. Geográfica América } \\
\text { Central }\end{array}$ & $88 \%$ & 1 & Dialnet \\
\hline Pensamiento Actual & $88 \%$ & o & None \\
\hline Humanitas & $88 \%$ & 1 & None \\
\hline Filología y Lingüística & $87 \%$ & 8 & Dialnet \\
\hline Actualidades en Psicología & $83 \%$ & 4 & $\begin{array}{l}\text { Redalyc } \\
\text { PePSIC }\end{array}$ \\
\hline TEC Empresarial & $83 \%$ & 2 & Dialnet \\
\hline InterSedes & $82 \%$ & 1 & Redalyc \\
\hline
\end{tabular}

Scholarly and Research

Communication

VOLUME 4 / ISSUE 1 / 2013 
Scholarly and Research Communication

VOLUME 4 / ISSUE 1 / 2013

\begin{tabular}{|l|l|l|l|}
\hline $\begin{array}{l}\text { Revista Costarricense de } \\
\text { Cardiología }\end{array}$ & $82 \%$ & 3 & SciELO \\
\hline $\begin{array}{l}\text { Revista CA de } \\
\text { Administración Pública }\end{array}$ & $79 \%$ & 3 & Dialnet \\
\hline Filosofía & $79 \%$ & 7 & Dialnet \\
\hline Enfermería Actual en CR & $78 \%$ & 3 & $\begin{array}{l}\text { Redalyc } \\
\text { Dialnet }\end{array}$ \\
\hline Comunicación & $73 \%$ & 2 & Redalyc \\
\hline Senderos & $64 \%$ & 1 & Dialnet \\
\hline Revista CR de Salud Pública & $\begin{array}{l}\text { Not yet } \\
\text { assessed }\end{array}$ & 3 & SciELO \\
\hline
\end{tabular}

SciELO *: Approved to be included in SciELO, not yet uploaded.

\section{Discussion}

It can be observed from Table 2 that the best-qualified journals are included in the various major portals. This is due to the similarity of selection criteria used by these portals (except for PePSIC, which includes only journals in Psychology). Thus, Dialnet, e-Revistas, ${ }^{6}$ and Redalyc ${ }^{7}$ have used the Latindex criteria as a starting point for their selection criteria, while SciELO-Costa Rica ${ }^{8}$ has incorporated them as an "indispensable starting point" (see http://www.scielo.sa.cr/avaliacao/avaliacao_es.htm). Redalyc and SciELO are perhaps the two portals that are most promoted among editors, although they are not necessarily more open to including new journal titles than other portals. With the recent signing of an agreement between Latindex and Dialnet, it is expected that the number of Costa Rican journals included will increase.

Costa Rica does not have a journal promotion and evaluation system as other Latin American countries do, such as Colombia (Publindex), Cuba (Cubaciencia), Argentina (Núcleo Básico de Revistas Científicas), and Mexico (Índice de Revistas Mexicanas de Investigación). For this reason, the public universities have directly adopted the Latindex Catalogue as a guide to classify and recognize their journals. As a result, one observes a strong presence of university journals in the Catalogue, as their editors make an effort to respond to the pressure of the scholarly evaluation systems. Moreover, these journals also receive comparatively more support in the form of financial resources and training of editors. In particular, the UCR does not approve the creation of a new journal that does not qualify for entry into the Catalogue, nor does it consider articles by university staff if they are not published in a journal with the Catalogue label. These policies have, of course, contributed to a strong positioning of Latindex, both institutionally (González, 2007) and on a national level.

Yet $55.4 \%$ of the Catalogue journals are not included in any of the portals, and consequently they are also absent from the PPL. On one hand, a number of editors are not yet aware of the importance for their journals of being included in indexing 
services and databases. On the other hand, many of the editors work under precarious circumstances and find it difficult to follow the recommendations and guidance provided in the workshops. Then there are other journals not edited by public institutions but that have made special efforts to be included in the Catalogue by inviting scholars to publish in them.

\section{Visibility of journals in a more developed country: The case of Spain}

\section{Visibility of Spanish journals: An overview}

Spain is today, according to Thomson Reuters' Essential Science Indicators and Scimago Journal \& Country Rank, ranked number 9 for its scientific production and 11 for the number of citations received. The amount of scholarly journals produced in Spain is quite impressive: 1698 in the social sciences and humanities, 277 in science and technology, and 240 in biomedical sciences. As of June 2010, 167 of these (8\%) were covered by WoS and 285 (13\%) by Scopus. These figures indicate a relatively high degree of visibility of the Spanish literature in the major international databases, especially if compared with the low presence in general of non-European or North American (and in particular of Latin American) journals in these databases.

This encouraging situation, however, is quite new, and certainly different from the one that prevailed fifteen years ago, when Latindex was first created. This is a reflection of a growing level of scientific activity and the increased competitiveness of Spanish researchers in the international scene. As the country has strengthened its research system, it has also paid attention to the evaluation of scientific activity, in response to the need to distribute appropriately the always limited economic resources available for R\&D. The various evaluation agencies (ANECA, CNEAI, and ANEP9) have been gradually refining their research evaluation criteria, specifically those that refer to publications, and in particular to scientific journals. A reflection on this evolution is necessary to understand how the role of Latindex has also changed over time.

\section{THE ROLE OF LATINDEX OVER TIME AND ITS COEXISTENCE WITH OTHER SYSTEMS}

At the time of the creation of Latindex, virtually the only database that was used as a reference to assess scientific production was the ISI-JCR (now WoS). That meant that a large part of Spanish production was left out of the evaluation process, since only a few of the Spanish journals were covered by ISI. The situation has improved considerably, as noted above, especially with the extension of the WoS coverage in 2008, which resulted in the inclusion of about 700 regional journal titles. ${ }^{10}$

On the other hand, even though over 1,500 titles were being published in all areas and disciplines, there was no program in support of these journals, and as a result, most did not follow any norms or standards, their distribution was poor, and the editors' work was far from professional. The advent of Latindex meant having for the first time an alternative to ISI as a reference on journal quality (without this implying any comparison between these tools). The Catalogue criteria became a tool for editors to guide them on the editorial quality aspects related to normalization, editorial management, and visibility. In this way, Latindex has played and continues to play an educational role among editors, while at the same time serving as a reference with
VOLUME 4 / ISSUE $1 / 2013$ 


\section{Scholarly and Research} Communication

VOLUME 4 / ISSUE 1 / 2013 valuable information for evaluators. This is not to imply that the mere presence of a journal in the Catalogue is equivalent to its presence in WoS. The evaluation systems (CNEAI and ANECA) assess the level of compliance of individual journals against the Latindex criteria in their (comparative) analysis of these publications, using the Catalogue as a threshold; thus, a journal that qualifies for the Catalogue is more likely to be considered a good scientific journal, compared with one that does not meet the minimum required. Evidently, even among the journals included in the Catalogue there are differences in quality, yet this part of the evaluation must be assumed by other systems (when they exist) or by experts in the various scientific disciplines.

Precisely the poor coverage of Spanish journals by WoS, and the large amount of scientific production that was consequently not assessed, motivated different research groups in Spain to develop journal evaluation systems in the last decade or so. This has been the case particularly in the area of the humanities and social sciences, in attention to the requirements introduced by evaluation agencies. ${ }^{11}$ Today we have the citation indexes In Recs, ${ }^{12}$ In Recj, and In Rech; the platforms RESH $^{13}$ and DICE, ${ }^{14}$ integrating various quality indicators; and the classification made by ANEP, ${ }^{15}$ all of which refer to national publications. Also, some systems with a clear international vocation have emerged, such as MIAR, ${ }^{16}$ which analyzes the visibility of publications through databases; the classification CARHUS; ${ }^{17}$ the newly created CIRC; ${ }^{18}$ or the ranking by impact in Scimago Country \& Journal RanK. ${ }^{19}$ Some of these systems are explicitly used as reference by agencies that evaluate scientific activity.

This means that Spanish evaluation agencies now have sufficient information services to obtain quality indicators on scientific journals, ranging from the more international ones, like WoS, Scopus, ERIH or CIRC, to the more local ones, such as DICE, In Recs, and MIAR, among others. Consequently, the proportion of Spanish scientific production that is not considered by any of these systems is clearly decreasing.

Given this wide variety of journal evaluation tools, one may ask whether the role of Latindex has evolved over the years. It certainly has; whereas initially Latindex (through the Catalogue) provided information on quality indicators for journals not covered by WoS, at present it serves to check if a journal meets the criteria considered to be indispensable for any scientific publication of quality. A journal that does not meet the criteria is excluded from the evaluation processes. Additional sources are used by evaluators to complete and refine their judgment, as was mentioned above for the case of Costa Rica (and as is the case in other Ibero-American countries).

From the above, it is clear that there exists a certain hierarchy of sources used in evaluation processes, in which a higher weight is given to a journal's presence in JCR than in DICE or Latindex. In this regard, it should be emphasized that Latindex, being essentially an information system, has never had the intention to compete with (other) journal evaluation systems. Each system (Latindex, DICE, RESH, and WoS) has its own aims, and evaluators, editors, and authors should use these reference tools without comparing them. Any scholarly journal may be included in Latindex, DICE, or RESH, but what is relevant is the journal's level of compliance with the quality indicators established by each system. Criteria considered by Latindex-referring to editorial quality-are less demanding than those covered by DICE and RESH, where impact, 
visibility, and internationality indicators, as well as expert opinion, are included. So this means that the best journal according to Latindex criteria is not necessarily the best journal according to DICE or RESH. Similarly, the best journal according to DICE criteria could be perfectly out of WoS.

A noteworthy aspect is a role that Latindex has played that is similar to some scholarly editor associations (such as the Council of Science Editors or the World Association of Medical Editors, to mention but two examples). Like them, Latindex establishes good editorial practices, monitors their compliance, and thus makes a first differentiation between publications. The 33/36 Catalogue criteria are grouped into three blocks, related to journal presentation, editorial management and policy, and contents. A number of these criteria refer to formal aspects, which has been the subject of some criticism, mostly by those who (incorrectly) see in Latindex one more journal evaluation system, rather than a comprehensive and reliable reference basis to be used as a tool for different specific evaluation purposes.

One may safely say that in a first instance, Latindex promotes the improvement of the journal quality. Clear evidence of this can be seen in Figure 2, which shows the evolution of quality indicators for Spanish journals in the humanities and social sciences between 2001 and 2011. This comparison has been made using the data on 17 Latindex quality indicators from A. Román, M. Vázquez Valero, and C. Urdín Camino (2002) as a baseline (see also Giménez-Toledo, 2011).

\section{fig.2. Evolution of quality indicators for Spanish journals in the humanities and social sciences, measured by percentage of compliance. Sources: DICE (2011) (see http://epuc.cchs.csic.es/dice) and Román et al. (2002).}

\section{A FURTHER DEVELOPMENT: THE PPL}

One additional role of Latindex, as said above, has been to give wider visibility to publications; moreover, the development of the PPL, by aggregating content from

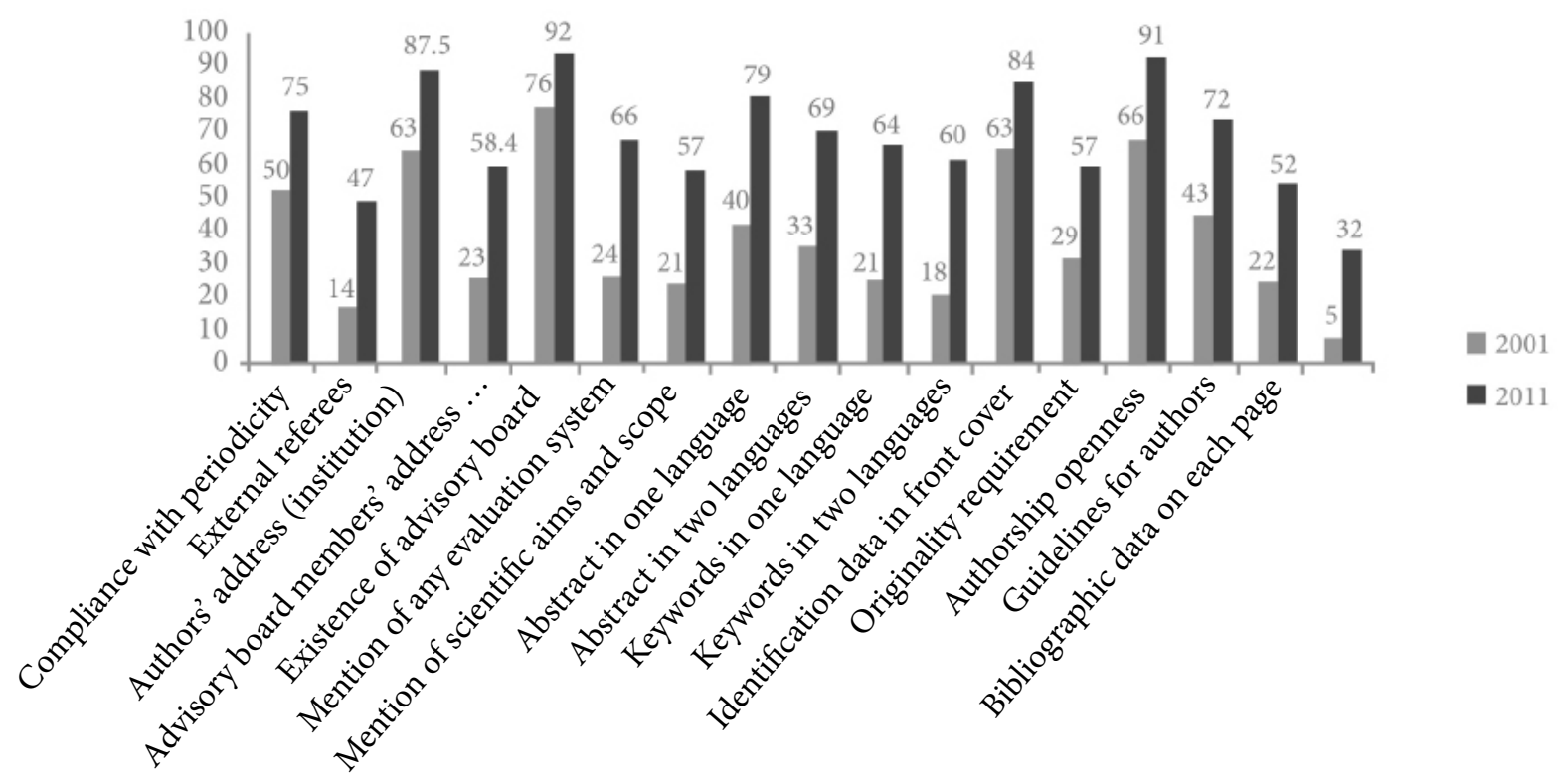

VOLUME 4 / ISSUE 1 / 2013 
Scholarly and Research Communication

VOLUME 4 / ISSUE 1 / 2013 different information systems, will clearly strengthen this role. Although as mentioned at the beginning of this section, Spanish scientific production is, to a certain extent, now recognized and has an acceptable level of visibility; this increase in international visibility is possible precisely thanks to the regional information systems, to open access, and to bibliographical databases. A wider visibility, if the journal is of sufficient quality, will enhance its recognition by the scholarly community, promote its citations, and thus facilitate its selection by the international databases that are preferentially used for evaluation purposes.

In this regard, the presence of Spanish journals in the PPL portals is already significant: 84 titles from the humanities and social sciences and 15 from the natural sciences are contained in Redalyc, 46 from the health sciences in SciELO and a large number of titles in e-Revistas, in addition to Dialnet, which virtually covers the full range of Spanish scholarly journals.

\section{Final remarks and conclusions}

A first general conclusion that can be drawn is that two of the major original objectives of Latindex, namely the improvement of editorial quality and an increase in journal visibility, are being largely met in the two case studies presented. This confirms the initial findings reported previously (see, e.g., Aguirre, Cetto, Córdoba, Flores, \& Román, 2006).

The expansion of bibliographical information products and journal evaluation systems is benefiting the Ibero-American scholarly community insofar as the scientific production of this region is becoming more visible and thus more easily read and cited. Nowadays, readers (basically, researchers and other scholars) expect to have online access, as immediately and directly as possible, to the entire relevant scientific literature. In this sense, the journal aggregators play a fundamental role by conveniently organizing the available literature. This is the role that the PPL is set out to play with regard to the scientific production contained in Ibero-American journals. It also provides the possibility of measuring the impact of papers through the number of searches and downloads, thereby attenuating the effects of exclusively using sources such as WoS or Scopus for the evaluation of scientific activity in the region (for critical accounts of these effects, see, for example, de la Peña, 2011; Laborde, 2011).

It is interesting to note that the hegemony of the two sources mentioned has not prevented the creation of diverse journal information and evaluation systems, not only in Ibero-America but also in different European countries - Australia, Russia, et cetera. This testifies to the convenience of having different systems coexist rather than staying with just a couple of systems that, since they are highly selective, leave out an important part of the scientific literature produced in different countries and languages.

Two unresolved dichotomies, at least, persist in the publishing scene. On one hand, one observes an increase in the visibility of journals, propitiated by electronic publishing, the use of metadata, open information systems, and aggregators like PPL or international databases. On the other hand, one can speak of an increased scientific recognition in the frame of evaluation agencies, and of a limited but growing collection 
of journals. It is thus necessary to distinguish between visibility and recognition by evaluation systems. The second dichotomy refers to those journals that have professional management, become visible, get recognized, and even become financially sustained, as opposed to those that are published with scarce resources and with a high workload concentrated among a few people, which barely manage to compete with those in the first group.

These considerations lead us to conclude that by providing guidance for quality improvement, options for visibility, and reference elements for evaluation processes, Latindex has different roles to play for journals in their different stages of development. Finally, as emphasized through the two case studies presented, it is important to bear in mind the objectives of the system before making use of it for scientific evaluation purposes.

\section{Notes}

1. When Latindex was created in 1997 , the total number of journal titles indexed by the UNAM databases was 2319: 1094 by CLASE (social sciences and humanities) and 1225 by Periódica (science, technology and medicine). The total number of registers indexed by these databases up to 1997 was 264,889 .

2. The decision to create the PPL was taken at the $13^{\text {th }}$ Latindex technical meeting in Buenos Aires, Argentina, in 2007. Suggestions made at the meeting by Dominique Babini from the Consejo Latinoamericano de Ciencias Sociales (CLACSO) are particularly appreciated.

3. For the complete table of online libraries analyzed, see Cetto et al. (2010, pp. 11-14).

4. See the Centro Centroamericano de Población (CCP), http://ccp.ucr.ac.cr.

5. The list of Latindex quality criteria can be found at http://www.latindex.org/ documentos/docu.html.

6. The quality criteria applied by e-Revistas can be found at http://www.erevistas.csic. es/criterioscalidad.php

7. The quality criteria applied by Redalyc can be found at http://redalyc.uaemex.mx/ redalyc/media/principal/proyecto/metvalref.html

8. Details about the selection criteria of SciELO-Costa Rica can be found at http:// www.scielo.sa.cr/avaliacao/avaliacao_es.htm

9. ANECA, the National Quality and Accreditation Evaluation Agency, is in charge of the evaluation, certification, and accreditation of teaching, lecturers and institutions; CNEAI, the National Research Assessment Commission, is in charge of the evaluation of university lecturers and researchers from public research centres; ANEP, the National Evaluation and Foresight Agency, is in charge of assessing research projects and programs, as well as undertaking studies and analysis of scientific research and technological development. 
Scholarly and Research

\section{Communication}

VOLUME 4 / ISSUE 1 / 2013
10. In WoS terminology, a journal is "regional" when it is not strictly international but is of interest to one or more countries.

11. Some examples of evaluation criteria introduced by agencies are: CNEAI, see http://www.boe.es/ boe/dias/2009/12/o1/pdfs/BOE-A-2009-19218.pdf; ANEP, Criterios de calidad en la investigación en Humanidades, see www.micinn.es/stfls/ MICINN/Investigacion/.../2007-criterios-hh.pdf ; and ANECA, for the assessment of academic staff, see http://www.aneca.es/var/media/551398/pep_2010_07_ ppios_070515.pdf.

12. See http://ec3.ugr.es/in-recs

13. See http://epuc.cchs.csic.es/resh

14. See http://epuc.cchs.csic.es/dice

15. Accessible through DICE; see http://epuc.cchs.csic.es/dice

16. See http://miar.ub.es/que.php

17. See http://www1o.gencat.net/agaur_web/AppJava/castellano/a_info. jsp?contingut=carhus

18. See http://epuc.cchs.csic.es/circ

19. See http://www.scimagojr.com

\section{References}

Aguirre, M., Cetto, A. M., Córdoba, S., Flores, A. M., \& Román, A. (2006). Calidad editorial y visibilidad de las revistas. In D. Babini \& J. Fraga (Eds.), Edición electrónica, bibliotecas virtuales y portales para las ciencias sociales en América Latina y el Caribe. Buenos Aires, Argentina: CLACSO.

Alonso-Gamboa, J. O., \& Russell, J. (2012). Latin American scholarly journal databases: A look back to the way forward. Aslib Proceedings, 64(1), 34-45.

Borrego Huerta, A. (2006). Acceso abierto: Valores nuevos para viejos actores. In B. Calleja \& M. Albornoz (Eds.), Diálogo entre editores científicos iberoamericanos. Buenos Aires, Argentina: CAICYT.

Cetto, A.M., Alonso-Gamboa, J. O., \& Córdoba González, S. (2010). Ibero-American systems for the dissemination of scholarly journals: A contribution to public knowledge worldwide. Scholarly and Research Communication, 1(1), 010104. URL: http://journals.sfu.ca/src/index.php/src/issue/ view/1 [March 18, 2012].

Córdoba, S. (2006). Visibilidad de las revistas de la Universidad de Costa Rica. Revista AIBDA, 27(1), 10-11.

de la Peña, J. A. (2011). Measuring scientific production: Uses and abuses. In A.M. Cetto \&

J. O. Alonso-Gamboa (Eds.), Calidad e impacto de la revista iberoamericana. México, D.F.:

Latindex, UNAM. URL: http://www.latindex.unam.mx/librociri/ [March 18, 2012]. 
Dávila, J., Núñez, L.A., Sandia, B., \& Torréns, R. (2006). Los repositorios institucionales y la preservación del patrimonio intelectual académico. Interciencia, 31(1), 22-28.

DICE. (2011). Online information system for the Spanish journals in the humanities and social sciences. URL: http://epuc.cchs.csic.es/dice [September 1, 2011].

Giménez-Toledo, E. (2011). Principios, valores e indicadores de calidad en los sistemas DICE, RESH y LATINDEX. Presentation at Encuentro Iberoamericano de Editores de Revistas Científicas de Ciencias Sociales, 20-21 July 2011, La Laguna (Tenerife), Spain.

González García, Y. (2007). VI Informe anual de labores. URL: http://www.ucr.ac.cr/medios/ documentos/2010/VI_Informe_Anual_Labores-209-236.pdf [September 1, 2011].

Laborde, J. (2011). The evaluation of researchers and the future of Latin American scientific journals. In A. M. Cetto \& J. O. Alonso-Gamboa (Eds.), Calidad e impacto de la revista iberoamericana. México, D.F.: Latindex, UNAM. URL: http://www.latindex.unam.mx/librociri/ [March 18, 2012].

Latindex. (2011). Online information system for Ibero-American scientific journals. URL: http://www. latindex.org.mx, http://www.latindex.org.mx [July 1, 2011].

McCabe, M. J. (2001). The impact of publisher mergers on journal prices. The Serials Librarian, 4o(1), 157-166.

McCabe, M. J. (2002). Journal prices and mergers: A portfolio approach. The American Economic Review, 92(1), 259-269.

Román, A., Vázquez Valero, M., \& Urdín Camino, C. (2002). Los criterios de calidad editorial Latindex en el marco de la evaluación de las revistas españolas de Humanidades y Ciencias Sociales. Revista Española de Documentación Científica, 25(3), 286-307.

UNAM. (2010). Portal de Portales Latindex. Informe técnico final: 30 de octubre de 2008-31 de marzo de 2010. Technical report. Dirección General de Servicios de Cómputo Académico, UNAM.

\section{Scholarly and Research}

Communication

VOLUME 4 / ISSUE 1 / 2013

Ana María Cetto, José Octavio Alonso-Gamboa, Saray Córdoba González, Elea Giménez-Toledo, Guillermo Chávez Sánchez. (2012). Organized access to the Ibero-American quality journals: The PPL experience. Scholarly and Research Communication, 4(1): 010135, 19 pp. 